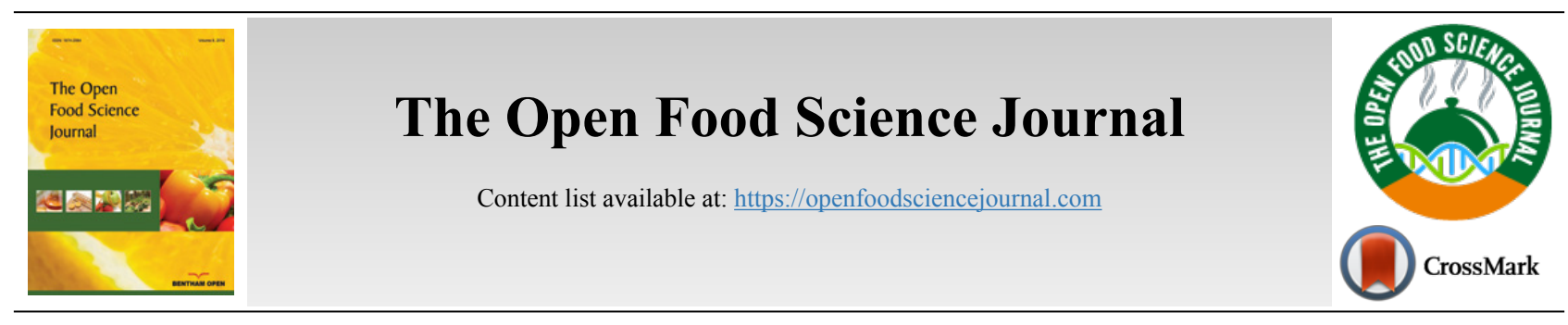

RESEARCH ARTICLE

\title{
Supercritical Fluid Extraction from Aguaje (Mauritia Flexuosa) Pulp: Overall Yield, Kinetic, Fatty Acid Profile, and Qualitative Phytochemical Profile
}

Larry Oscar Chañi-Paucar ${ }^{1}$, Edgar Torres Yali ${ }^{2}$, Júlio César Maceda Santivañez ${ }^{3}$, Dina Aro Garcia ${ }^{2}$ Júlio C F Jonher $^{1}$ and Maria Angela A Meireles, ${ }^{1, *}$

${ }^{1}$ School of Food Engineering, University of Campinas, Rua Monteiro Lobato, 80, CEP, 13083-862, Campinas, SP, Brazil

${ }^{2}$ Escuela Profesional de Ingeniería Agroindustrial, Universidad Nacional Amazónica de Madre de Dios (UNAMAD), Av. Jorge Chávez s/n, ZIP Code: 17001, Madre de Dios, Peru

${ }^{3}$ Bioprospection and Biotechnology Laboratory, National Institute of Amazonian Research, Av. Andre Araujo, 2936, CEP, 69067-375, Manaus, Brazil

\footnotetext{
Abstract:

Aims:

This work aims to understand the effects of processing variables on supercritical fluid extraction from Mauritia flexuosa (Aguaje). This is not a cultivar because the plants used are indigenous.

Background:

The production of Mauritia flexuosa (Aguaje) is an economically significant activity in Madre de Dios, Peru, which has rarely been studied from a nutritional point of view.

Objective:

The present study evaluated the supercritical extraction of dry aguaje pulp (DAP).

Methods:

The supercritical extraction was evaluated at 200,250,300,350, and 400 bar and temperatures of 40 and $60^{\circ} \mathrm{C}$, and its effect on the global yield, fatty acid profile (FAP), and qualitative phytochemical profile (QPP). The kinetics data were fitted to the Spline model. The FAP was determined by gas chromatography, and the QPP was determined by thin-layer chromatography.

Results:

The highest yield (51.5 g extract $/ 100 \mathrm{~g}$ DAP) was observed at $400 \mathrm{bar}$ and $60^{\circ} \mathrm{C}$ in $79 \mathrm{~min}$ of extraction and $8.6 \mathrm{~g} \mathrm{CO} / \mathrm{min}$. The spline model showed that it is possible to extract $87.8 \%$ (45.2 g extract $/ 100 \mathrm{~g}$ DAP) of the total extract in the $\mathrm{t}_{\mathrm{FER}}$ (falling rate period) period ( $\left.38.99 \mathrm{~min}\right)$. The fatty acid and bioactive compound profiles were not affected qualitatively by the different extraction conditions.

Research perspectives:

The extracts obtained in this work were further studied with respect to the formation of emulsions, the development of cosmetics, and food supplements.

Conclusion:

DAP's supercritical extraction was carried out successfully, obtaining a high-quality phytochemical extract with potential applications in functional foods, drugs, and cosmetics.
}

Keywords: Aguaje pulp, Supercritical fluid extraction, Edible oil, Fatty acids, Phytochemicals, Mauritia flexuosa. 


\section{INTRODUCTION}

Mauritia flexuosa is a palm tree species distributed throughout the Amazon region of Bolivia, Brazil, Colombia, Ecuador, French Guiana, Guyana, Suriname, Trinidad-Tobago, Venezuela, and Peru [1]. In Peru, the palm and fruit are known under the name "Aguaje"; the cities of Iquitos and Loreto are often reported as the most significant producers [2, 3]. However, other cities in Peru, such as Madre de Dios, have an important but little-known production. The production is derived from natural plantations with or without association with conventional crops such as palm trees.

The pulp of Aguaje from Madre de Dios is popularly known for its high lipid content, but there are no scientific studies that evaluated the lipid profile of the fruits of this region. Proximal analysis of Aguaje from other regions of the Peruvian Amazon has reported the following values for pulp + shell: humidity of $54.4 \%$, fiber content of $10.1 \%$, the lipid content of $18.1 \%$, the ash content of $1.2 \%$, the protein content of $2.3 \%$, and carbohydrate content of $13.9 \%$ [4]. Aguaje oil has captured researchers' interest for its content in fatty acids, carotenoids, tocopherols, tannins, and flavonoids [5, 6]. Recent research shows interesting results of the application of Aguaje oil in the elaboration of functional foods [7] as a protector against the mutagenic effects of drugs used in cancer chemotherapy [8] in the manufacture of photoprotective creams and lotions $[9,10]$. Therefore, new applications of Aguaje oil is obtained through clean and safe processes, which does not present potential health risks.

Although the extraction of lipids with organic solvents is efficient $[11,12]$, there is a potential risk to human health, for instance, cancer and other diseases, due to traces of these toxic solvents and the possible reactions that can trigger ethereal extracts. Cold mechanical extraction presents variable yields depending on the extraction temperature $[4,11]$. Furthermore, the extraction is not selective; then, filtering and neutralization operations with $\mathrm{NaOH}$ are necessary. On the other hand, the method of supercritical fluid extraction (SFE), especially with $\mathrm{CO}_{2}$, applied to the extraction of pulps from oleaginous fruits allows high yields of high-quality extracts to be obtained without potentially harmful organic solvent residues. SFE with or without cosolvent depends on the process temperature, pressure, and amount of cosolvent; the kinetics of the process depends on the $\mathrm{CO}_{2}$ flow, particle size, and solvent mass/feed mass (S/F) [13 - 15].

In the search for the scientific literature available in the SCOPUS and Web of Science databases, using no restrictions and the term "Supercritical fluids extraction Mauritia flexuosa," only one article describing the Aguaje oil extraction by SFE was found [5]. This study focused mainly on the extra-

\footnotetext{
Address correspondence to this author at School of Food Engineering, University of Campinas, Rua Monteiro Lobato, 80, CEP: 13083-862, Campinas, SP, Brazil; E-mail: maameireles@lasefi.com
}

ction of carotenoids, noting that the most considerable fraction of the pigment was extracted with the oil in the diffusioncontrolled step, which shows that a complete recovery of the oil is necessary. These authors reported an efficient oil extraction $(\sim 7.5 \mathrm{~g}$ oil $/ 100 \mathrm{~g}$ sample $)$ at $300 \mathrm{bar}$ and $40^{\circ} \mathrm{C}$, using a 95 min time, flow rate of $18.4 \mathrm{~g} \mathrm{CO}_{2} / \mathrm{min}$, and an $\mathrm{S} / \mathrm{F}$ of 24. The effect of pressure and temperature on the extraction yield is not clear, mainly because only two pressures (200 and 300 bar) were used in the assays. The solubility of lipid compounds in sc- $\mathrm{CO}_{2}$ varies with both temperature and pressure, directly affecting the lipid compounds' vapor pressure and the density of $\mathrm{CO}_{2}$ (therefore, its solvation power) [16]. As Aguaje oil is a complex mixture of compounds $[5,11]$ and aiming at complete extraction, it is pertinent to evaluate the effect of pressure on the extraction yield in shorter pressure intervals (every 50 bar).

Aguaje oil has a significant amount of fatty acids, predominantly unsaturated fatty acids $[4,11]$. There is no report in the literature on the effect of SFE conditions on the fatty acid composition of Aguaje oil. For instance, Cordeiro et al. [17], and Ndayishimiye et al. [18], reported the effects of SFE conditions on the extracts of Virola surinamensis seed oil and citrus residues (seeds and skins), respectively.

Several properties are attributed to Aguaje oil, such as its antimicrobial activity [19], regulation of iron accumulation [20], antiplatelet and antithrombotic activities [21] and antimutagenic effect [8]. In these studies, these properties are attributed to fatty acids and carotenoids. Nevertheless, these studies are not conclusive since the oil was solely used in the activity tests, and the chemical composition profile was not addressed. Therefore, other unidentified compounds may act concomitantly, making it necessary to perform a phytochemical screening. Based on these considerations, the present study aimed to evaluate the supercritical $\mathrm{CO}_{2}$ extraction of oil from Aguaje pulp at different pressures (200, 250, 300, 350, and 400 bar) and temperatures $\left(40\right.$ and $\left.60^{\circ} \mathrm{C}\right)$, analyzing the effects of these variables on the fatty acid profile and qualitative phytochemical profile.

\section{MATERIALS AND METHODS}

\subsection{Raw Material}

The fruits of Aguaje (M. flexuosa) were harvested from a small farmer's farm, located $5 \mathrm{~km}$ from Puerto Maldonado city, on the road known as "Corredor Turístico Chonta - Infierno" in the Joya District, Tambopata Province, Madre de Dios Department, Peru (Fig. 1A). Aguaje fruits were harvested by climbing to the palm trees' top with a belt adapted for this task (Fig. 1B). The clusters of Aguaje fruits were cut with a machete and allowed to fall to the ground (Fig. 1C). Then, the fruits were manually removed from the bunches with the help of a machete and transported to the farmer's residence, where the fruit conditioning phase began, to obtain the dry pulp of Aguaje. 

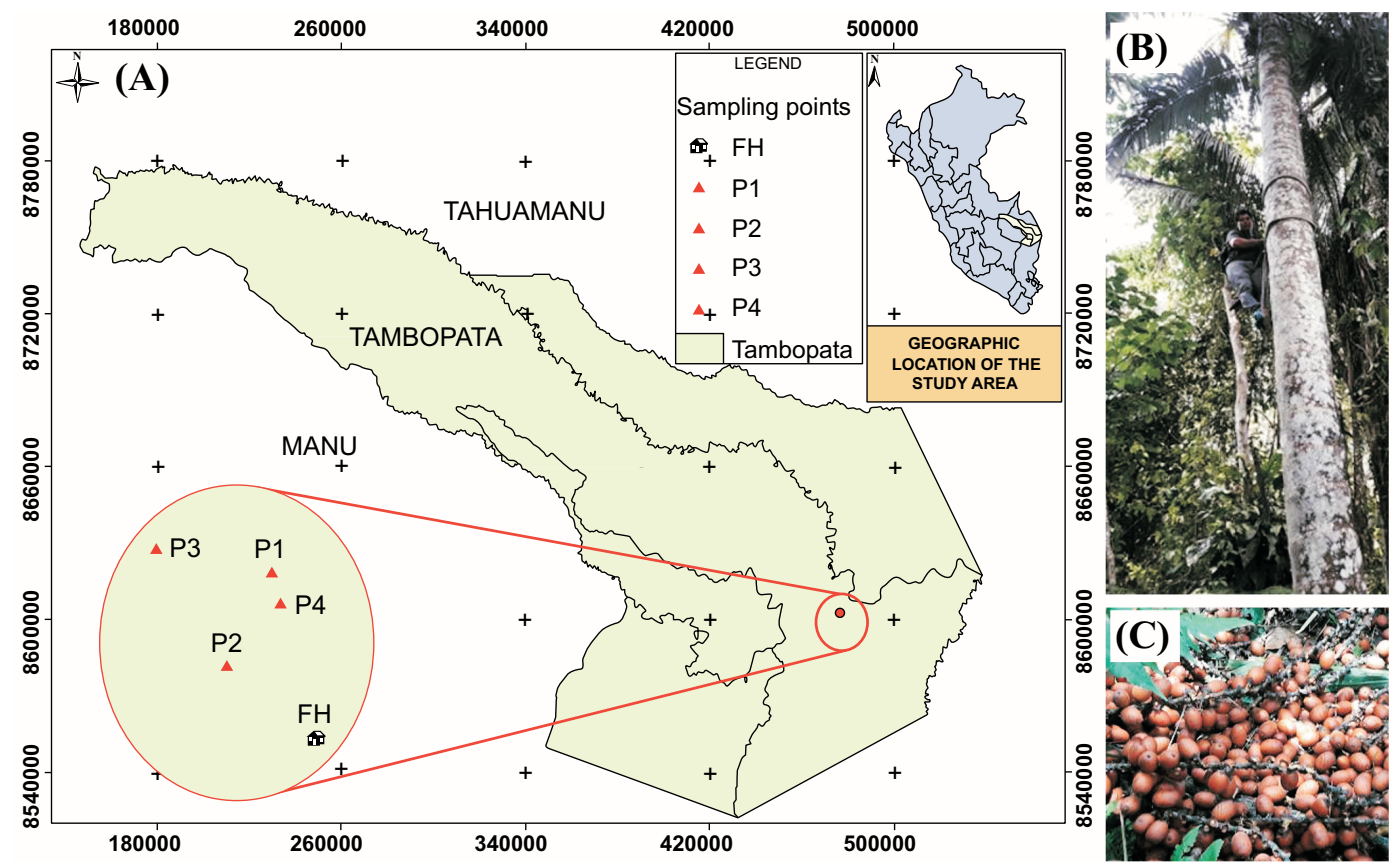

Fig. (1). Aguaje fruit harvest location map (A), including sampling points P1 (east 476213, and north 8602633), P2 (east 476186, and north 8602584), P3 (east 476144, and north 8602646), P4 (east 476218, and north 8602617), and the farmer's house (FH: east 476239, and north 8602545). Harvest (B), and fruits (C).

\subsection{Sample Preparation}

After harvesting, Aguaje fruits clean and free from debris were subjected to thermal treatment in a homemade manner. In short, the treatment was carried out by heating in an aluminum pan (Record, Peru) $24 \mathrm{~kg}$ of Aguaje fruits with approximately 24 liters of water until reaching a temperature between 35 and $40^{\circ} \mathrm{C}$. This temperature was kept constant until the pulp was soft; this was achieved in approximately 30 minutes. The period of heat treatment was defined using two empirical criteria: the ease of manually removing the peels and the softening of the pulp. After the heat treatment, the fruits were peeled and pulped manually with a spoon's aid; the pulp was packed in polyethylene bags and stored at $-20^{\circ} \mathrm{C}$.

The frozen pulp was transported to the Laboratory of Agroindustrial Processes, Faculty of Agroindustrial Engineering of the National University of Madre de Dios (UNAMAD), where it was thawed at room temperature. Afterward, it was subjected to drying in an oven with air circulation at $40^{\circ} \mathrm{C}$ for 16 hours. These conditions were lower than those used by de França et al. [5], $\left(60^{\circ} \mathrm{C}\right.$ and 24 hours $)$ to prevent thermolabile bioactive compounds' degradation. The dried pulp was packed in polyethylene bags of one kilogram and stored with protection from light at $-20^{\circ} \mathrm{C}$. They were transported to the Laboratory of Supercritical Technology (LASEFI), of the School of Food Engineering (FEA), of the University of Campinas (UNICAMP), São Paulo, Brazil, where subsequent data collections were carried out.

\subsection{Supercritical Extraction of Oil from Aguaje Pulp}

The extractions were carried out using the equipment Speed (Applied Separations, model 7071, Allentown, USA), with a micrometric valve heated by a homemade system (Fig. 2, detail
V4), composed of electrical resistance, a temperature controller, a temperature sensor and a vat containing distilled water without forced circulation, where the micrometric valve body was submerged, and the vat water temperature was maintained at approximately $55 \pm 2{ }^{\circ} \mathrm{C}$. The cooling bath temperature was constant at $-2 \pm 1^{\circ} \mathrm{C}$ for cooling the pneumatic $\mathrm{CO}_{2}$ pump head (Fig. 2, detail 3).

The extraction experiments were carried out, combining temperatures of 40 and $60^{\circ} \mathrm{C}$ with pressures of 200, 250, 300, 350 , and 400 bar, for a total of 10 assays. Approximately $23 \mathrm{~g}$ of dry Aguaje pulp (DAP) was used for each extraction; this mass amount allowed the complete filling of the $25 \mathrm{~mL}$ stainless steel extraction column. After packaging the sample and installing the extraction column in the equipment, the blocking valve (Fig. 2, detail V1) of the $\mathrm{CO}_{2}$ cylinder $(99.9 \%$ pure, White Martins, Campinas, Brazil) was opened. The blocking valve located immediately before the extraction column (Fig. 2, detail V2) was also opened, maintaining the extraction column outlet blocking valve (Fig. 2, detail V3) closed; this last valve remained closed for 10 minutes; this period is denoted as static time. After the static time (10 min), the extraction column outlet blocking valve (Fig. 2, detail V3) was opened, starting the dynamic extraction period that lasted 38 minutes. The $\mathrm{CO}_{2}$ mean flow rate was maintained at 8.9 $\mathrm{g} / \mathrm{min}$ and manually regulated with the micrometer valve (Fig. 2, detail V4). The extract was collected in $100 \mathrm{~mL}$ glass flasks protected from light with aluminum foil. After the extraction was completed, the flasks were closed and stored at $-20^{\circ} \mathrm{C}$ until the analyses were performed.

The effect of the extraction conditions was assessed by determining the OEY (g extract/100 g DAP) with Equation 1: where OEY is the overall extraction yield; $\mathrm{m}_{\mathrm{oil}}$ is the mass of 
the extract in grams; and $m_{\mathrm{DAP}}$ is the mass of the DAP used for extraction in grams.

$$
0 E Y(g \text { extract } / 100 g \text { DAP })=\frac{m_{\text {extract }}(\mathrm{g})}{m_{\text {DAP }}(\mathrm{g})} \times 100
$$

\subsection{Extraction Kinetics}

The kinetic extraction curve was constructed by plotting the accumulated extraction yield (g extract/100 g DAP) versus the extraction time (min). The extraction was carried out with approximately $23 \mathrm{~g}$. DAP under pressure and temperature conditions that obtained the best performance, as determined in the previous assays. The extraction had an approximate duration of $79 \mathrm{~min}$. This time does not include the static period, which had a duration of $10 \mathrm{~min}$. During the dynamic extraction, eighteen collections were made to build the extraction kinetics. The mathematical modeling of the experimental data was performed using the model described by Meireles [22], which describes that typically the overall extraction curve (OEC) presents three different regions with different extraction rates. Initially, a period of constant extraction rate (CER) is established in which the extract contained on the surface of the particles is removed mainly by convection. The following region is characterized by a period of falling extraction rate (FER) in which extraction is carried out by convection and diffusion. Finally, a period controlled by diffusion (DC) is established.

The mathematical spline model is shown in Equation 2, where $\mathrm{m}_{\text {Ext }}$ is the extraction yield (g extract/100 g DAP); $a_{1}, a_{2}$ and $a_{3}$ are slope coefficients (first-order terms) of the straight lines CER, FER and DC, respectively $\left(\mathrm{min}^{-1}\right)$; $\mathrm{t}_{\mathrm{CER}}$ is the time interval of the CER period (min); and $t_{\mathrm{FER}}$ is the end of the FER period (min).

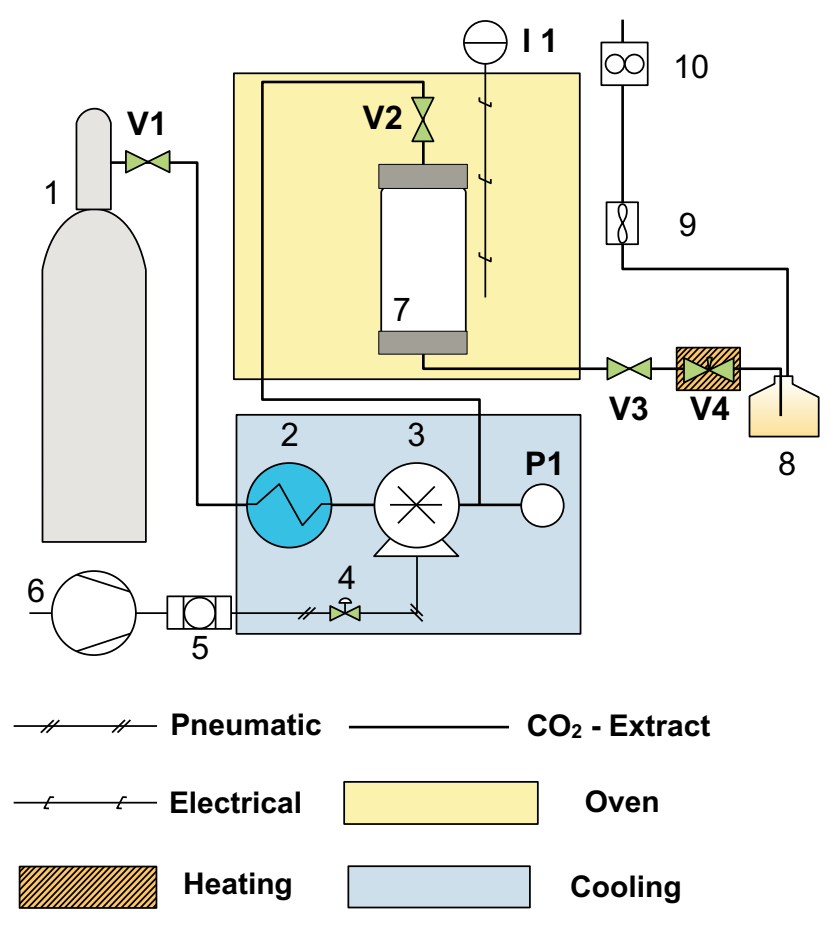

\begin{tabular}{|c|l|c|l|}
\hline 1 & $\mathrm{CO}_{2}$ reservoir & 9 & Flowmeter \\
\hline 2 & Cooling bath & 10 & Flow totalizer \\
\hline 3 & Air-driven $\mathrm{CO}_{2}$ pump & I1 & Temperature Indicator \\
\hline 4 & Control (air pressure) & P1 & Pressure gauge \\
\hline 5 & Air filter & V1 & Blocking valve \\
\hline 6 & Air compressor & V2 & Blocking valve \\
\hline 7 & Extraction cell & V3 & Blocking valve \\
\hline 8 & Extract collecting vessel & V4 & Micrometering valve \\
\hline
\end{tabular}

Fig. (2). Schematic diagram of the supercritical extractor. (Applied Separations Inc, Allentown, USA). 


$$
\begin{gathered}
m_{E x t}=a_{1} t ; \quad t \leq t_{C E R} \\
m_{E x t}=a_{1} t+a_{2}\left(t-t_{C E R}\right) ; \quad t_{C E R}<t \leq t_{F E R} \\
m_{E x t}=a_{1} t+a_{2}\left(t-t_{C E R}\right)+a_{3}\left(t-t_{F E R}\right) ; \quad t_{F E R} \leq t
\end{gathered}
$$

\subsection{Determination of the Fatty Acids Composition}

The extracts obtained under different pressure and temperature conditions were analyzed to determine their fatty acid composition. The extract was esterified to obtain fatty acid methyl esters (FAME) with approximately $0.5 \mathrm{~g}$ of extract, 10 $\mathrm{mL}$ of methanol, 2 drops of $\mathrm{H}_{2} \mathrm{SO}_{4}$, and reflux for 2 hours [23]. FAMEs were extracted with hexane and organic phase injection in an Agilent 6890 gas chromatograph. The chromatograph was equipped with a Stabilwax column (30 $\mathrm{m} \times$ $0.25 \mathrm{~mm} ; 0.25 \mu \mathrm{m}$ ) and a flame ionization detector (FID). Helium was used as the carrier gas, and the temperature was programmed as follows: at $45^{\circ} \mathrm{C}$ for 2 minutes, at $5^{\circ} \mathrm{C} / \mathrm{min}$ up to $50^{\circ} \mathrm{C}$, at $30^{\circ} \mathrm{C} / \mathrm{min}$ up to $250^{\circ} \mathrm{C}$, with isotherm for 10 minutes. The injector and detector temperatures were adjusted to $250^{\circ} \mathrm{C}$ and $280^{\circ} \mathrm{C}$, respectively.

The identification of fatty acids was carried out by comparing the retention times of FAMEs obtained from Aguaje extracts with the profile of a FAME pattern (Supelco, C8-C24 p/n CRM18918, Bellefonte, PA, USA) analyzed under the same chromatographic conditions. Fatty acids were quantified by calculating the percentages of peak areas for each FAME, reporting as a relative percentage (\%) [24].

\subsection{Qualitative Phytochemical Characterization}

The extract samples were subjected to thin-layer chromatography (TLC) analysis, according to the methodologies proposed by Wagner et al. [25], to show the different classes of chemical substances. Silica gel 60 chromatoplates $(5 \mathrm{~cm} \times 5 \mathrm{~cm}$, Macherey - NageL-MN $®)$ were used, impregnated with a 0.20 $\mathrm{mm}$ thick UV254 $\mathrm{nm}$ fluorescence indicator (manganese activated zinc silicate with green fluorescence). Two lines were gently marked with $0.5 \mathrm{~cm}$ graphite pencil from the beginning and end of the chromatoplate, leaving $4 \mathrm{~cm}$ of space for the separation of chemical substances. The extracts were previously solubilized ( 1 part of extract: 3 parts of hexane), and with the aid of a capillary tube, they were applied over the line drawn at the bottom of the chromatoplate. The chromatoplate was then placed in a glass vat containing an elution composed of hexane and ethyl acetate $(9: 1 \mathrm{v} / \mathrm{v})$. The chemical substances present in the chromatoplates were developed using physical methods (ultraviolet light at wavelengths 254 and $365 \mathrm{~nm}$ ) and chemical methods. Five developers, the anisaldehyde reagent sulfuric acid (AS), Dragendorff reagent (DRG), ceric sulfate $\left(\mathrm{Ce}\left(\mathrm{SO}_{4}\right)_{2}\right)$, potassium hydroxide $(\mathrm{KOH})$ and ferric chloride $\left(\mathrm{FeCl}_{3}\right)$ were prepared according to the method proposed by Wagner and Bladt [26] and Wagner et al. [25], with some modifications that are detailed below:

The AS reagent was prepared by mixing $0.5 \mathrm{~mL}$ of anisaldehyde, $10 \mathrm{~mL}$ of glacial acetic acid, $85 \mathrm{~mL}$ of methanol, and $5 \mathrm{~mL}$ of concentrated sulfuric acid. Flavonoids, terpenes, fatty acids, iridoids, and sugars emit colors between red-violet in visible light and UV-365 $\mathrm{nm}$ after heating the chromatoplates sprayed with the developer.

Ferric chloride $\left(\mathrm{FeCl}_{3}\right)$ was prepared by dissolving $3 \mathrm{~g}$ of $\mathrm{FeCl}_{3}$ in $100 \mathrm{~mL}$ of ethyl alcohol. Aromatic compounds are visible after spraying the reagent.

DRG was prepared by mixing two solutions. The first solution (I) was prepared by dissolving $0.85 \mathrm{~g}$ of basic bismuth nitrate in $10 \mathrm{~mL}$ of glacial acetic acid under heating; this solution was added to $40 \mathrm{~mL}$ of distilled water. The second solution (II) was prepared by dissolving $8 \mathrm{~g}$ of potassium iodide in $20 \mathrm{~mL}$ of distilled water. The two solutions were mixed; $5 \mathrm{~mL}$ of solution I with $5 \mathrm{~mL}$ of solution II, and $20 \mathrm{~mL}$ of acetic acid were added, followed by the addition of distilled water to complete $100 \mathrm{~mL}$. Alkaloids, heterocyclic nitrogen compounds, and quaternary amines are detectable in visible light on chromatoplates sprayed with this developer.

$\mathrm{KOH}$ was prepared by dissolving $1 \mathrm{~g}$ of $\mathrm{KOH}$ in $100 \mathrm{~mL}$ of ethanol. The chromatoplate sprayed with this developer was evaluated under visible light and UV-365 nm without heating. The detectable compounds are anthraquinones (red), anthrones (yellow, UV-365 nm), and coumarins (blue, UV-365 nm).

The developer $\mathrm{Ce}\left(\mathrm{SO}_{4}\right)_{2}$ was prepared according to Khalid et al. [27], and Stahl [28] with some modifications: $4.2 \mathrm{~g}$ of cerium sulfate IV was dissolved in $500 \mathrm{~mL}$ of distilled water, $2.8 \mathrm{~mL}$ of concentrated sulfuric acid was added and heated, and then allowed to cool. This solution was completed in $100 \mathrm{~mL}$ of distilled water. Terpenes, sterols, and other similar compounds show visible spots after heat treatment of the sprayed chromatoplate with this developer.

\subsection{Calculation of the Kinetics Parameters}

The experimental data were expressed as the average of two repetitions from the extraction assays, kinetics, and fatty acids' composition. The modeling of the extraction kinetics Equations 2.a - 2.c was performed using the genetic algorithm (GA) with MATLAB software (MathWorks, version R12). The fit quality of the experimental data to the Spline model was evaluated considering the objective function defined as the absolute average relative deviation (AARD) referred to the yield expressed by Equation 3 [29]:

$$
\operatorname{AARD}(\%)=\frac{100}{n} \sum_{i=1}^{n}\left|\frac{x_{i, \exp }-x_{i, c a l}}{x_{i, \exp }}\right|
$$

where AARD is the average absolute relative deviation $(\%), \mathrm{n}$ is the number of data points, and $\mathrm{x}_{\mathrm{i}, \text { exp }}$ and $\mathrm{x}_{\mathrm{i}, \text { cal }}$ refer to the experimental and calculated yields for data $\mathrm{i}$, respectively.

\section{RESULTS AND DISCUSSION}

\section{1. $\mathrm{SFE}-\mathrm{CO}_{2}$}

Table 1 shows that the OEY obtained in all experimental conditions was higher than the highest OEY ( $7.8 \mathrm{~g}$ extract/100 g DAP) reported by de França et al. [5], employing the same extraction method. Our results were also superior to the OEYs found in hexane extraction [12], discontinuous mechanical 
pressing [4], and continuous [11]. The results obtained were superior to the OEY of extraction with petroleum benzene [11] at pressures of 350 and 400 bar for the two isotherms (Fig. 3). The differences observed in the OEY of our study compared to those in the literature (Table 1) are probably due to the higher solubility of the Aguaje extract achieved due to the increase in the $\mathrm{CO}_{2}$ solvation power under the studied conditions. Additionally, the Aguaje pulp used in this study had a high lipid content compared to that reported in the literature (Table 1). OEY at different pressure and temperature conditions was plotted against the pressure and density of the sc- $\mathrm{CO}_{2}$ obtained in the two isotherms (Fig. 3).

In general, at the two extraction temperatures (40 and $60^{\circ} \mathrm{C}$ ), the OEY increased when the increase in pressure. At $40^{\circ} \mathrm{C}$, the lowest extraction yield was $23.5 \%$ at $200 \mathrm{bar}$, and the highest yield was $36.2 \%$ at 400 bar. At $60^{\circ} \mathrm{C}$, the lowest yield observed was $24.5 \%$ at 200 bar, and the highest yield was $41.1 \%$ at 400 bar. At the $60^{\circ} \mathrm{C}$ isotherms, it was observed that the extraction yield increased in the 200 to 300 bar range; a similar trend was observed for the $40^{\circ} \mathrm{C}$ isotherm. From 300 bar in the $60^{\circ} \mathrm{C}$ isotherm, the yield increased substantially up to 400 bar (Fig. 3).



Fig. (3). Extraction yield at different pressures $\left(200,250,300,350\right.$, and 400 bar) and temperatures $\left(40\right.$ and $\left.60^{\circ} \mathrm{C}\right)$ with supercritical carbon dioxide.

Table 1. Current literature on supercritical, mechanical, and solvent extraction of M. flexuosa pulp and other palm trees in the Amazon.

\begin{tabular}{|c|c|c|c|c|c|c|c|c|c|c|}
\hline $\mathbf{R M}$ & EM & SS & $\begin{array}{c}\text { Pressure } \\
\text { (bar) }\end{array}$ & \begin{tabular}{|c|} 
Temperature \\
$\left({ }^{\circ} \mathrm{C}\right)$
\end{tabular} & $\begin{array}{c}\text { TE } \\
(\mathrm{min})\end{array}$ & \begin{tabular}{|c|} 
Flow rate \\
$(\mathrm{g}$. \\
$\left.\mathrm{CO}_{2} / \mathrm{min}\right)$
\end{tabular} & \begin{tabular}{|l|}
$\mathrm{S} / \mathbf{F}$ \\
$(\mathrm{g} / \mathrm{g})$
\end{tabular} & \begin{tabular}{|c|} 
Oil \\
yield $* *$ \\
$(\%$ \\
mass $)$
\end{tabular} & Composition* & Reference \\
\hline M. flexuosa & SFE-CO ${ }_{2}$ & Pará-Brazil & $\begin{array}{c}200 \text { and } \\
300\end{array}$ & 40 and 55 & $\begin{array}{l}95- \\
210\end{array}$ & $\begin{array}{c}16.8- \\
31.8\end{array}$ & \begin{tabular}{c|}
$24-$ \\
39
\end{tabular} & $\begin{array}{c}4.7- \\
7.8\end{array}$ & $\begin{array}{c}\text { Carotenoids, tocopherols, } \\
\text { and fatty acids }\end{array}$ & $\begin{array}{c}\text { França et } \\
\text { al. }[5]\end{array}$ \\
\hline M. flexuosa & $\begin{array}{c}\text { Mechanical } \\
\text { extraction } \\
\text { continues }\end{array}$ & Guaviare-Colombia & NR & $25-30$ & - & - & - & 22 & \multirow{2}{*}{$\begin{array}{l}\text { Triglycerides, diglycerides, } \\
\text { fatty acids, acylcarnitine, } \\
\text { ceramides, ergosterol, } \\
\text { lysophosphatidylcholine, } \\
\text { phosphatidyl, } \\
\text { ethanolamine, and } \\
\text { sphingolipids }\end{array}$} & \multirow[t]{2}{*}{$\begin{array}{c}\text { Jaramillo et } \\
\text { al. }[11]\end{array}$} \\
\hline M. flexuosa & $\begin{array}{c}\text { Solvent } \\
\text { extraction } \\
\text { (petroleum } \\
\text { benzine) }\end{array}$ & Guaviare-Colombia & - & $40-60$ & NR & - & - & 33 & & \\
\hline M. flexuosa & $\begin{array}{c}\text { Solvent } \\
\text { extraction } \\
\text { (Hexane) }\end{array}$ & Roraima-Brazil & - & NR & 360 & - & - & 23.2 & $\begin{array}{c}\text { Omegas } 3(\omega 3), 6(\omega 6) \text { and } \\
9(\omega 9)\end{array}$ & $\begin{array}{c}\text { Santos } e t \\
\text { al. [12] }\end{array}$ \\
\hline M. flexuosa & $\begin{array}{c}\text { Mechanical } \\
\text { extraction }\end{array}$ & Loreto-Perú & 392.3 & 25 and 60 & 20 & - & - & $\begin{array}{l}4.0- \\
17.9\end{array}$ & fatty acids & $\begin{array}{c}\text { Jacobo et } \\
\text { al. }[4]\end{array}$ \\
\hline $\begin{array}{l}\text { Mauritia } \\
\text { aculeata }\end{array}$ & $\begin{array}{c}\text { Solvent } \\
\text { extraction } \\
\text { (Hexane) }\end{array}$ & Roraima-Brazil & - & $\mathrm{NR}$ & 360 & - & - & 26 & $\begin{array}{c}\text { Omegas } 3(\omega 3), 6(\omega 6) \text { and } \\
9(\omega 9)\end{array}$ & $\begin{array}{c}\text { Santos et } \\
\text { al. [12] }\end{array}$ \\
\hline $\begin{array}{l}\text { Acrocomia } \\
\text { aculeata }\end{array}$ & SFE-CO ${ }_{2}$ & Brazil & $180-220$ & $40-80$ & 200 & $\begin{array}{l}1.62- \\
2.67^{\mathrm{a}}\end{array}$ & \begin{tabular}{|c|}
$19-$ \\
31
\end{tabular} & $\begin{array}{l}9.3- \\
41.6\end{array}$ & $\begin{array}{c}\text { Free fatty acids, phytosterol } \\
\text { (Campesterol and } \beta- \\
\text { sitosterol) and tocopherol } \\
(\alpha, \delta \text {, and } \gamma)\end{array}$ & $\begin{array}{c}\text { Trentini et } \\
\text { al. }[30]\end{array}$ \\
\hline
\end{tabular}




\begin{tabular}{|c|c|c|c|c|c|c|c|c|c|c|}
\hline $\begin{array}{c}\text { Acrocomia } \\
\text { aculeata }\end{array}$ & $\begin{array}{c}\text { Solvent } \\
\text { extraction } \\
\text { (n-Hexane) }\end{array}$ & Brazil & - & 68 & 480 & - & - & 43.7 & $\begin{array}{c}\text { Free fatty acids, phytosterol } \\
(\beta \text {-sitosterol) and } \\
\text { tocopherol }(\alpha, \delta \text {, and } \gamma)\end{array}$ & $\begin{array}{c}\text { Trentini et } \\
\text { al. }[30]\end{array}$ \\
\hline $\begin{array}{c}\text { Oenocarpus } \\
\text { bacaba }\end{array}$ & SFE-CO ${ }_{2}$ & Pará-Brazil & $120-420$ & 40 and 60 & 180 & 5.31 & 48 & $\begin{array}{l}4.3- \\
60.4 \\
\end{array}$ & fatty acids & $\begin{array}{c}\text { Pinto et al. } \\
{[31]} \\
\end{array}$ \\
\hline $\begin{array}{c}\text { Oenocarpus } \\
\text { bacaba }\end{array}$ & $\begin{array}{c}\text { Solvent } \\
\text { extraction } \\
\text { (n-Hexane) }\end{array}$ & Roraima-Brazil & - & NR & 360 & - & - & 43.9 & $\begin{array}{c}\text { Omegas } 3(\omega 3), 6(\omega 6) \text { and } \\
9(\omega 9)\end{array}$ & $\begin{array}{l}\text { Santos et } \\
\text { al. [12] }\end{array}$ \\
\hline M. flexuosa & SFE-CO ${ }_{2}$ & Madre de Dios-Perú & $200-400$ & 40 and 60 & 38 & 8.9 & 14.7 & $\begin{array}{c}23.5- \\
41.1\end{array}$ & $\begin{array}{c}\text { Fatty acid } \\
\text { Terpenoids*** }\end{array}$ & $\begin{array}{l}\text { Current } \\
\text { study }\end{array}$ \\
\hline
\end{tabular}

RM: Raw material; EM: Extraction method; SS: Sample source; TE: Extraction time;

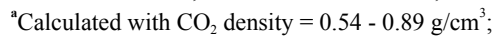

* It only reflects what the authors researched at that time;

** Mass of extract/mass of dry raw material;

***Detection of the presence of terpenic compounds by TLC.

The OEY observed in this study showed the expected behavior when pressure and temperature increased (Fig. 3B) because these two parameters modify the density and other properties of $\mathrm{CO}_{2}$ (solvent): The increase in $\mathrm{CO}_{2}$ solvation power is due to the increase in the density, while the vapor pressure of the extract decreases, facilitating solubilization [16, $31,32]$. The increase in the $\mathrm{CO}_{2}$ density contributes to the increase in the DAP extract's solubility in the solvent, which led to an increase in the OEY (Fig. 3B). There was a small increase in the OEY (between 1.7 and 3.9\%) in the pressure range of $200-300$ bar as the temperature increased from 40 to $60^{\circ} \mathrm{C}$ (Fig. 3). At 300 bar, the $\mathrm{OEY}$ was equal as the temperature increased from 40 to $60^{\circ} \mathrm{C}(32 \pm 2$ and $32 \pm 0.3 \%$, respectively); therefore, the phenomenon known as retrogradation is detected at this pressure. Bouazzaoui et al. [33], observed this same phenomenon in the extraction of oil from Cucumis melo seeds at 700 bar for a similar temperature variation $\left(40\right.$ to $\left.57^{\circ} \mathrm{C}\right)$. This retrogradation pressure was higher than that observed in our study, which was probably due to the difference in the composition of fatty acids in C. melo oil (68.2\% polyunsaturated fatty acids) and Aguaje oil. At pressures of 350 and $400 \mathrm{bar}$, increasing the temperature (40 to $60^{\circ} \mathrm{C}$ ) led to a substantial increase in the OEY (Fig. 3). A similar effect was reported for the Virola surinamensis extraction study at 350 bar and 40 to $80^{\circ} \mathrm{C}$ [17], Oenocarpus bacaba at 420 bar and 40 to $60^{\circ} \mathrm{C}$ [31] and Aleurites moluccana at 350 bar and 40 to $60^{\circ} \mathrm{C}$ [34]. Cunha et al. [14], reported a different behavior for SFE from Oenocarpus distichus Mart., registering an increase in $\mathrm{OEY}$ of less than $1 \%$ as the temperature increased from 50 to $60^{\circ} \mathrm{C}$ in the pressure range from 350 to 420 bar. This behavior allowed us to infer that variations in solubility due to the variation in temperature and pressure in the studied ranges did not change $O$. distichus oil's extraction yield in $\mathrm{CO}_{2}$, which did not occur in our study.

\subsection{Spline Model}

The kinetic parameters were obtained by fitting the OEC (Fig. 4, 400 bar and $60^{\circ} \mathrm{C}$ ) to the spline model. The kinetics were evaluated for a maximum period of $79 \mathrm{~min}$, reaching an $\mathrm{S} / \mathrm{F}$ ratio of 29 and an accumulated yield of $51.5 \mathrm{~g}$ extract $/ 100$ g DAP. The kinetic curve showed three periods with different extraction rates, which are well represented by the spline model's three straight lines, as shown in Fig. (4). The model was adequately fitted to the experimental data according to the calculated AARD value, which was less than $10 \%$; this value is within the range recommended by other authors [29]. According to Meireles [22] and Jesus et al. [35], the first straight line with an inclination of $4.1047 \mathrm{~min}^{-1}$ (Table 2) predominates a period of extraction at a constant rate (CER), obtained by convection of the extract of easy access that involves the solid particles of DAP. The following straight line, with a slope of $0.7498 \mathrm{~min}^{-1}$ (Table 2), shows a period of decreasing extraction rate (FER). In this period, the extraction is carried out by both convection and diffusion. The last straight line, with a slope of $0.1635 \mathrm{~min}^{-1}$ (Table 2), represents the period in which the extraction rate is controlled by diffusion (DC).

The curve's constants with three straight lines obtained by the Spline model are shown in Table 2, and in $\mathrm{t}_{\mathrm{FER}}(39.0 \mathrm{~min})$, $45.2 \mathrm{~g}$ extract $/ 100 \mathrm{~g}$ DAP was obtained, which is approximately $87.8 \%$ of the total extractable substances. A different situation was reported by de França et al. [5], who reported a yield of $6.8 \mathrm{~g}$ extract/100 $\mathrm{g}$ DAP in the $\mathrm{t}_{\mathrm{CER}}(53.6$ $\min )$ at 300 bar and $40^{\circ} \mathrm{C}$. These differences can be explained by the higher temperature and pressure used in the present study, obtaining a higher yield (Fig. 4). The results are promising for projects to scale up the process due to the high yield obtained and a lower $\mathrm{CO}_{2}$ flow rate (Table 1) used in this study with respect to that reported in the consulted literature.

Table 2. Numeric values of the Spline model constants for 400 bar and $60^{\circ} \mathrm{C}$.

\begin{tabular}{|c|c|c|c|c|c|c|c|}
\hline \multirow{2}{*}{ Extraction method } & \multicolumn{5}{|c|}{ Constant } & \multicolumn{1}{c|}{ ARRD (\%) } \\
\cline { 2 - 7 } & $\boldsymbol{a}_{\boldsymbol{1}}$ & $\boldsymbol{a}_{2}$ & $\boldsymbol{a}_{3}$ & $\boldsymbol{t}_{\text {CER }}$ & $\boldsymbol{t}_{\text {FER }}$ & $\boldsymbol{t}_{\text {total }}$ & \\
\hline $\mathrm{SFE}-\mathrm{CO}_{2}$ & 4.1047 & 0.7498 & 0.1635 & 4.77 & 38.99 & 79 & 8.32 \\
\hline \multicolumn{7}{|c|}{$\mathrm{a}_{1}, \mathrm{a}_{2}$ and $\mathrm{a}_{3}\left(\mathrm{~min}^{-1}\right) ; t_{C E R}, t_{\text {FER }}$, and $t_{\text {total }}(\mathrm{min})}$. \\
\hline
\end{tabular}




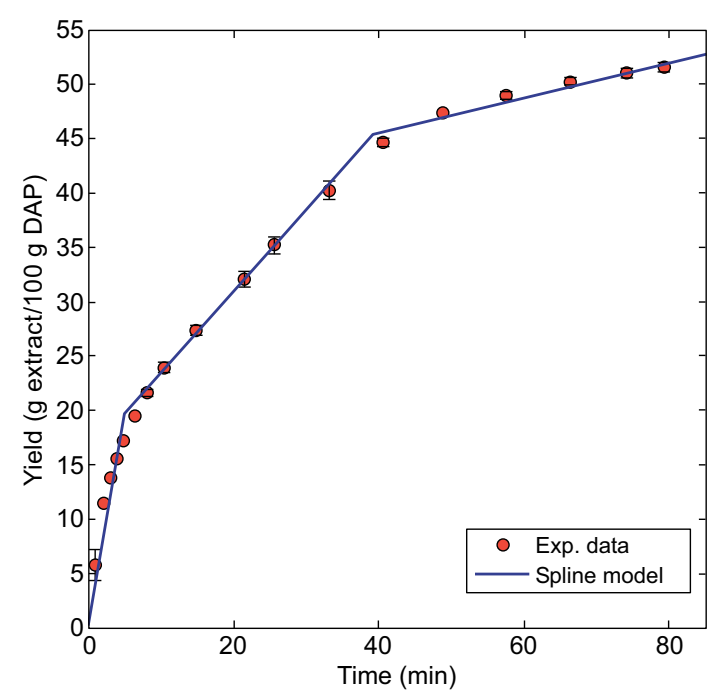

Fig. (4). Extraction curve at $400 \mathrm{bar}, 60^{\circ} \mathrm{C}$, and $8.6 \mathrm{~g} \mathrm{CO}_{2} / \mathrm{min}$.

\subsection{Composition of Fatty Acids}

The DAP OEY varied due to the effect of temperature and pressure. Nevertheless, these two factors did not affect the fatty acid (FA) profile, showing only small variations in the concentration of FA (Table 3). Cunha et al. [14], proved a similar effect on the $O$. distichus $\mathrm{SFE}$ at pressures of 150 to 420 bar and temperatures of $50^{\circ} \mathrm{C}$ and $60^{\circ} \mathrm{C}$, observing a standard deviation less than $1.8 \%$ in the content for all FAs. Similarly, Pinto et al. [31], reported that under different SFE conditions (pressure: 120 to 420 bar and temperature: 40 and $60^{\circ} \mathrm{C}$ ) of $O$. bacaba, the qualitative profile of the oil was similar, registering variations in the FA content but the predominance of UFA, which varied from $71.9 \%$ to $74.0 \%$. The similar effect observed in these two studies was probably due to the similarity in the composition of the FA of the two raw materials, with a more significant predominance of oleic acid in both cases, which could also explain our results. On the other hand, the FA's profile and content in Virola surinamensis oil extracted at 350 bar was varied by the effect of temperature (in the range of 40 to $80^{\circ} \mathrm{C}$ ). In all treatments, the oil was mainly composed of lauric acid (17.3 to $23.5 \%$ ) and myristic acid (71.7 to $77.6 \%$ ), increasing and decreasing their concentrations, respectively, with the temperature variation.

The extract obtained in the present study showed three saturated fatty acids (SFAs), two monounsaturated fatty acids
(MUFAs), and two polyunsaturated fatty acids (PUFAs). The relative percentages of palmitic, stearic, and arachidic SFAs varied from 21 to $22 \%$, from 1.5 to $1.8 \%$, and from 0.33 to $0.75 \%$, respectively. MUFA, palmitoleic, and oleic contents varied from 0.53 to $0.67 \%$ and from 71 to $74 \%$, respectively. PUFAs, linoleic and linolenic varied from 1.5 to $2.2 \%$ and from 0.87 to $1.6 \%$. As evident, there is a more significant predominance of oleic and palmitic acid. A higher number of FAs was observed in the DAP extract in our study than in the study by de França et al. [5]. They reported the presence of palmitic acid (17.3\%), oleic acid (78.7\%) and linoleic acid $(3.9 \%)$ in the oil obtained by SFE- $\mathrm{CO}_{2}$. Similarly, Jaramillo et al. [11], reported the presence of three FAs in the oil extracted with petroleum benzine, myristoleic acid $(13.6 \%)$, palmitic acid $(22.9 \%)$, and oleic acid (63.5\%). The profile and composition of FA closer to that reported in this study was shown by Jacobo et al. [4], applying mechanical extraction at $60^{\circ} \mathrm{C}$, the oil obtained by this method in addition to the FA shown in Table $\mathbf{1}$, cis-vaccenic (1.3\%) and gondoic acids $(0.3 \%)$. Nevertheless, the oil had a high oleic acid content $(74.6 \%)$ and palmitic acid (18.4\%), which is characteristic of Aguaje pulp. Although small variations in the FA content were recorded (Table 1), it was possible to observe that the PUFAs extracted at $60^{\circ} \mathrm{C}$ and 400 bar were in a higher percentage $(3.8 \%)$.

\subsection{Qualitative Profile}

Table 4 shows the results of the assays with the five developers (AS, DRG, $\mathrm{Ce}\left(\mathrm{SO}_{4}\right)_{2}, \mathrm{KOH}$, and $\mathrm{FeCl}_{3}$ ). The AS and $\mathrm{Ce}\left(\mathrm{SO}_{4}\right)_{2}$ developers enabled the detection of phytochemicals. In Fig. (5), dark blue stains can be observed with $R_{f} 0.13$ and 0.65 for chromatoplate $A 1$, and with $R_{f} 0.11$ and 0.55 for chromatoplate A3. This staining is likely to be terpenes after derivatization with AS, as illustrated by Wagner et al. [25]. Still, other compounds could also react and emit a similar color because the developer AS is also used in the qualitative identification of compounds such as flavonoids, fatty acids, iridoids, and sugars. With the developer $\mathrm{Ce}\left(\mathrm{SO}_{4}\right)_{2}$, it was possible to see two brown spots, as seen in chromatoplates $A 2$ and A3 in Fig. (5), which appeared in $R_{f} 0.13$ and 0.65 for chromatoplate $\mathrm{A} 2$, and in $\mathrm{R}_{\mathrm{f}} 0.11$ and 0.55 for chromatoplate A4. Due to the nature of the sample and the extraction method, it is believed that the compounds that generated these stains are terpenes and/or sterols, but other compounds soluble in sc- $\mathrm{CO}_{2}$ may also be present. Therefore, it is of great interest to carry out further studies to elucidate which compounds are present in the DAP extract extracted by $\mathrm{sc}-\mathrm{CO}_{2}$ to better explain the functional properties reported in the current scientific literature.

Table 3. Fatty acid composition (\%) of DAP extract extracted at different temperatures and pressures.

\begin{tabular}{|c|c|c|c|c|c|c|c|c|c|c|}
\hline \multirow[t]{3}{*}{ Fatty acid (\%)* } & \multicolumn{5}{|c|}{$40^{\circ} \mathrm{C}$} & \multicolumn{5}{|c|}{$60^{\circ} \mathrm{C}$} \\
\hline & \multicolumn{5}{|c|}{ Pressure (bar) } & \multicolumn{5}{|c|}{ Pressure (bar) } \\
\hline & 200 & 250 & 300 & 350 & 400 & 200 & 250 & 300 & 350 & 400 \\
\hline $\mathrm{C} 16: 0$ & $21 \pm 1$ & $22 \pm 1$ & $22 \pm 1$ & $22 \pm 1$ & $22 \pm 1$ & $22 \pm 1$ & $22 \pm 1$ & $22 \pm 1$ & $22 \pm 1$ & $22 \pm 1$ \\
\hline C16:1 & $0.53 \pm 0.01$ & $0.63 \pm 0.01$ & $0.59 \pm 0.01$ & $0.65 \pm 0.01$ & $0.65 \pm 0.01$ & $0.58 \pm 0.01$ & $0.58 \pm 0.02$ & $0.56 \pm 0.01$ & $0.62 \pm 0.01$ & $0.67 \pm 0.06$ \\
\hline C18:0 & $1.80 \pm 0.1$ & $1.5 \pm 0.1$ & $1.7 \pm 0.1$ & $1.5 \pm 0.1$ & $1.5 \pm 0.1$ & $1.6 \pm 0.1$ & $1.7 \pm 0.1$ & $1.8 \pm 0.1$ & $1.6 \pm 0.1$ & $1.6 \pm 0.1$ \\
\hline C18:1 & $74 \pm 1$ & $72 \pm 1$ & $73 \pm 1$ & $72 \pm 1$ & $72 \pm 1$ & $73 \pm 1$ & $72 \pm 1$ & $73 \pm 1$ & $72 \pm 1$ & $71 \pm 1$ \\
\hline
\end{tabular}


(Table 3) contd.....

\begin{tabular}{|c|c|c|c|c|c|c|c|c|c|c|}
\hline C18:2 & $1.5 \pm 0.1$ & $1.8 \pm 0.1$ & $1.7 \pm 0.1$ & $1.9 \pm 0.1$ & $1.7 \pm 0.1$ & $1.7 \pm 0.1$ & $1.8 \pm 0.1$ & $1.6 \pm 0.1$ & $1.8 \pm 0.1$ & $2.2 \pm 0.4$ \\
\hline C18:3 & $0.87 \pm 0.01$ & $1.1 \pm 0.1$ & $1.0 \pm 0.1$ & $1.2 \pm 0.1$ & $1.1 \pm 0.1$ & $1.0 \pm 0.1$ & $1.1 \pm 0.1$ & $0.95 \pm 0.03$ & $1.1 \pm 0.1$ & $1.6 \pm 0.4$ \\
\hline C20:0 & $0.6 \pm 0.1$ & $0.43 \pm 0.09$ & $0.33 \pm 0.01$ & $0.47 \pm 0.01$ & $0.75 \pm 0.08$ & $0.53 \pm 0.01$ & $0.65 \pm 0.03$ & $0.53 \pm 0.01$ & $0.62 \pm 0.02$ & $0.67 \pm 0.09$ \\
\hline SFA (\%) & $23 \pm 1$ & $24 \pm 1$ & $23 \pm 1$ & $24 \pm 1$ & $24 \pm 1$ & $24 \pm 1$ & $24 \pm 1$ & $24 \pm 1$ & $24 \pm 1$ & $24 \pm 1$ \\
\hline MUFA (\%) & $75 \pm 1$ & $73 \pm 1$ & $74 \pm 1$ & $73 \pm 1$ & $73 \pm 1$ & $74 \pm 1$ & $72 \pm 58$ & $74 \pm 1$ & $73 \pm 1$ & $72 \pm 1$ \\
\hline PUFA (\%) & $2.4 \pm 0.1$ & $2.9 \pm 0.2$ & $2.7 \pm 0.2$ & $3.1 \pm 0.2$ & $2.8 \pm 0.2$ & $2.7 \pm 0.2$ & $2.9 \pm 0.2$ & $3 \pm 1$ & $2.9 \pm 0.2$ & $3.8 \pm 0.8$ \\
\hline
\end{tabular}

Palmitic acid (C16: 0); Palmitoleic acid (C16: 1); Stearic acid (C18: 0); Oleic acid (C18: 1); Linoleic acid (C18: 2); Linolenic acid (C18: 3); Arachidic acid (C20: 0); SFA:

Saturated fatty acids; MUFA: Monounsaturated fatty acids; PUFA: Polyunsaturated fatty acids.

* Mean values \pm standard deviation $(\mathrm{n}=2)$.

Table 4. Phytochemical profile determined by thin-layer chromatography (TLC) of the DAP extract obtained under different extraction conditions.

\begin{tabular}{|c|c|c|c|c|c|}
\hline Extraction conditions & Anisaldehyde - sulfuric acid & $\left.\mathrm{Ce}_{(\mathbf{S O}}\right)_{2}$ & $\mathrm{KOH}$ & $\mathrm{FeCl}_{3}$ & Dragendorff \\
\hline $200 \mathrm{bar}-40^{\circ} \mathrm{C}$ & + & + & - & - & - \\
\hline $250 \mathrm{bar}-40^{\circ} \mathrm{C}$ & + & + & - & - & - \\
\hline $300 \mathrm{bar}-40^{\circ} \mathrm{C}$ & + & + & - & - & - \\
\hline $350 \mathrm{bar}-40^{\circ} \mathrm{C}$ & + & + & - & - & - \\
\hline $400 \mathrm{bar}-40^{\circ} \mathrm{C}$ & + & + & - & - & - \\
\hline $200 \mathrm{bar}-60^{\circ} \mathrm{C}$ & + & + & - & - & - \\
\hline $250 \mathrm{bar}-60^{\circ} \mathrm{C}$ & + & + & - & - & - \\
\hline $300 \mathrm{bar}-60^{\circ} \mathrm{C}$ & + & + & - & - & - \\
\hline $350 \mathrm{bar}-60^{\circ} \mathrm{C}$ & + & + & - & - & - \\
\hline $400 \mathrm{bar}-60^{\circ} \mathrm{C}$ & + & + & - & - & - \\
\hline & $(+)$ Presence, $(-)$ Absence & & \\
\hline
\end{tabular}


Fig. (5). Identification (A1 and $\mathrm{A} 3$ - anisaldehyde developer) and confirmation ( $\mathrm{A} 2$ and $\mathrm{A} 4-\mathrm{Ce}\left(\mathrm{SO}_{4}\right)_{2}$ developer) of terpenes by thin-layer chromatography of the DAP extract extracted by SFE at different temperatures and pressures.

Compounds of a terpenic nature have not been reported so far in Aguaje oil extracted by $\mathrm{sc}-\mathrm{CO}_{2}$, but the results observed in this study show evidence of presence of these compounds. Terpenes have already been reported in the leaves of $M$. 
flexuosa palm, managing to identify the presence of a diterpene (phytol) and a monoterpene (citronellol), both with essential applications in the cosmetic, food and pharmacologic industries, especially citronellol, as it is a GRAS (generally recognized as safe) substance [36].

\section{CONCLUSION}

The pulp of M. flexuosa from the collection region is promising for industrial use due to its high lipid content. Supercritical extraction of DAP with $\mathrm{CO}_{2}$ was performed successfully, and the best extraction conditions were 400 bar and $60^{\circ} \mathrm{C}$. Under this condition, it is possible to extract $51.5 \mathrm{~g}$ extract/100 g DAP in approximately 79 minutes of the process with a constant flow rate of $8.6 \mathrm{~g} \mathrm{CO}_{2} / \mathrm{min}$. The spline model allowed us to characterize the extraction kinetics satisfactorily, observing three extraction periods, CER, FER, and CD, with extraction rates controlled by mass transfer mechanisms by convection, convection-diffusion, and diffusion, respectively. Approximately $87.8 \%$ of the extractable DAP at 400 bar and $60^{\circ} \mathrm{C}$ is obtained in the $t_{\mathrm{FER}}$ period $(38.99 \mathrm{~min})$. It would be necessary to extend the extraction process for another $40 \mathrm{~min}$ to obtain the DAP's total extract; this is not a good practice when considering the process. Therefore, this kinetic point $\left(t_{\mathrm{FER}}\right)$ is interesting for scale-up studies. The different extraction conditions did not affect the fatty acid profile or the qualitative phytochemical profile, observing the probable presence of compounds from the terpene family. Because of the results obtained, it is necessary to extend the studies for processing on an industrial scale and potential applications in functional foods, drugs, and cosmetics.

\section{ETHICS APPROVAL AND CONSENT TO PARTICIPATE}

Not applicable.

\section{HUMAN AND ANIMAL RIGHTS}

No animals/humans were used for studies that are the basis of this research.

\section{CONSENT FOR PUBLICATION}

Not applicable.

\section{AVAILABILITY OF DATA AND MATERIALS}

Not applicable.

\section{FUNDING}

This study was financed in part by the Higher Education Improvement Coordination - Brazilian Government Institution (CAPES) - Finance Code 001. Larry O. Chañi-Paucar also thanks CONCYTEC-FONDECYT (Peru) for the research internship scholarship [CONTRATO $\mathrm{N}^{\circ}$ 156-2018-FONDECYT]. M. A. A. Meireles acknowledges the productivity grant from CNPq (302423/2015-0).

\section{CONFLICT OF INTEREST}

The authors declare no conflicts of interest, financial or otherwise.

\section{ACKNOWLEDGEMENTS}

This study was supported by Higher Education Improvement Coordination - Brazilian Government Institution (CAPES).

\section{REFERENCES}

[1] Global Biodiversity Information Facility https://www.gbif.org

[2] Virapongse A, Endress BA, Gilmore MP, Horn C, Romulo C. Ecology, Livelihoods, and Management of the Mauritia Flexuosa Palm in South America. Glob Ecol Conserv 2017; 10: 70-92. [http://dx.doi.org/10.1016/j.gecco.2016.12.005]

[3] Endress BA, Gilmore MP, Vargas Paredes VH, Horn CM. Data on spatio-temporal patterns of wild fruit harvest from the economically important palm Mauritia flexuosa in the Peruvian Amazon. Data Brief 2018; 20: 132-9.

[http://dx.doi.org/10.1016/j.dib.2018.07.045] [PMID: 30112428]

[4] Jacobo F, Rojas M, Reyes GI, Pino EL. Caracterización de Aceites, Tortas y Harinas de Frutos de Ungurahui (Jessenia Polycarpa) y Aguaje (Mauritia Flexuosa) de La Amazonía Peruana. Rev Soc Quím Perú 2009; 75: 243-53.

[5] de França LF, Reber G, Meireles MAA, Machado NT, Brunner G. Supercritical Extraction of Carotenoids and Lipids from Buriti (Mauritia Flexuosa), a Fruit from the Amazon Region. J Supercrit Fluids 1999; 14(3): 247-56.

[http://dx.doi.org/10.1016/S0896-8446(98)00122-3]

[6] Nobre CB, Sousa EO, Camilo CJ, et al. Antioxidative effect and phytochemical profile of natural products from the fruits of "babaçu" (Orbignia speciose) and "buriti" (Mauritia flexuosa). Food Chem Toxicol 2018; 121: 423-9.

[http://dx.doi.org/10.1016/j.fct.2018.08.068] [PMID: 30172848]

[7] Aquino J de S, Pessoa DCN de P, de Oliveira CEV, Cavalheiro JMO, Stamford TLM. Processamento de Biscoitos Adicionados de Óleo de Buriti (Mauritia Flexuosa L.): Uma Alternativa Para o Consumo de Alimentos Fontes de Vitamina A Na Merenda Escolar. Rev Nutr 2012; 25(6): 765-74.

[http://dx.doi.org/10.1590/S1415-52732012000600008]

[8] Ribeiro J, Antunes L, Darin J, Mercadante A, Bianchi MDL. Buriti (mauritia flexuosa) oil: Evaluation of the mutagenic and antimutagenic potential by the micronucleus test in vivo. Toxicol Lett 2010; 2010(196): S163-4.

[http://dx.doi.org/10.1016/j.toxlet.2010.03.561]

[9] Zanatta CF, Mitjans M, Urgatondo V, Rocha-Filho PA, Vinardell MP. Photoprotective potential of emulsions formulated with Buriti oil (Mauritia flexuosa) against UV irradiation on keratinocytes and fibroblasts cell lines. Food Chem Toxicol 2010; 48(1): 70-5. [http://dx.doi.org/10.1016/j.fct.2009.09.017] [PMID: 19766688]

[10] Zanatta CF, Ugartondo V, Mitjans M, Rocha-Filho PA, Vinardell MP. Low cytotoxicity of creams and lotions formulated with Buriti oil (Mauritia flexuosa) assessed by the neutral red release test. Food Chem Toxicol 2008; 46(8): 2776-81.

[http://dx.doi.org/10.1016/j.fct.2008.05.001] [PMID: 18558457]

[11] Cardona Jaramillo JEC, Carrillo Bautista MP, Alvarez Solano OA, Achenie LEK, González Barrios AF. Impact of the mode of extraction on the lipidomic profile of oils obtained from selected amazonian fruits. Biomolecules 2019; 9(8): 329.

[http://dx.doi.org/10.3390/biom9080329] [PMID: 31374835]

[12] Santos RC, Chagas EA, de Melo Filho AA, et al. Chemical characterization of oils and fats from amazonian fruits by $1 \mathrm{H}$ NMR. Chem Eng Trans 2018; 64: 235-40.

[http://dx.doi.org/10.3303/CET1864040]

[13] Johner JCF, Hatami T, Meireles MAA. Developing a supercritical fluid extraction method assisted by cold pressing for extraction of pequi (caryocar brasiliense). J Supercrit Fluids 2018; 137: 34-9. [http://dx.doi.org/10.1016/j.supflu.2018.03.005]

[14] Cunha VM, da Silva MP, de Sousa SH, do Nascimento Bezerra P, Menezes EG, da Silva NJ. Bacaba-de-leque (Oenocarpus distichus Mart.) oil extraction using supercritical $\mathrm{CO} 2$ and bioactive compounds determination in the residual pulp. J Supercritical Fluids 2019; 144: $81-90$.

[http://dx.doi.org/10.1016/j.supflu.2018.10.010]

[15] Corzzini SCS, Barros HDFQ, Grimaldi R, Cabral FA. Extraction of edible avocado oil using supercritical $\mathrm{CO}_{2}$ and a $\mathrm{CO}_{2}$ /ethanol mixture as solvents. J Food Eng 2017; 194: 40-5.

[http://dx.doi.org/10.1016/j.jfoodeng.2016.09.004] 
[16] Jash A, Hatami T, Rizvi SSH. Phosphatidylcholine solubility in supercritical carbon dioxide: Experimental data, thermodynamic modeling, and application in bioactive-encapsulated liposome synthesis. J Supercrit Fluids 2020; 158104720

[http://dx.doi.org/10.1016/j.supflu.2019.104720]

[17] Cordeiro RM, Ana AP, Pinto RHH, et al. Supercritical $\mathrm{CO}_{2}$ extraction of ucuúba (virola surinamensis) seed oil: Global yield, kinetic data, fatty acid profile, and antimicrobial activities. Chem Eng Commun 2019; 206(1): 86-97.

[http://dx.doi.org/10.1080/00986445.2018.1474741]

[18] Ndayishimiye J, Getachew AT, Chun BS. Comparison of characteristics of oils extracted from a mixture of citrus seeds and peels using hexane and supercritical carbon dioxide. Waste Biomass Valoriz 2017; 8(4): 1205-17.

[http://dx.doi.org/10.1007/s12649-016-9697-8]

[19] Pereira YF, Costa MDS, Tintino SR. Modulation of the antibiotic activity by the mauritia flexuosa (Buriti) fixed oil against methicillinresistant staphylococcus aureus (MRSA) and other multidrug-resistant (MDR) bacterial strains. Pathogens 2018; 7(4): 1-8.

[http://dx.doi.org/10.3390/pathogens7040098]

[20] Aquino J de S, Tavares RL, Medeiros L de B, Martins CC de L, Pessoa DCN de P, Stamford TLM. Effect of the consumption on buriti oil on the metabolism of rats induced by iron overload. Arch Endocrinol Metab 2015; 59(5): 422-7.

[http://dx.doi.org/10.1590/2359-3997000000105] [PMID: 26421670]

[21] Fuentes E, Rodríguez-Pérez W, Guzmán L, et al. Mauritia flexuosa Presents in vitro and in vivo Antiplatelet and Antithrombotic Activities. Evid Based Complement Alternat Med 2013; 2013653257 [http://dx.doi.org/10.1155/2013/653257] [PMID: 24454503]

[22] Meireles MAA. Extraction of Bioactive Compounds from Latin American Plants. 2008.

[23] Hartman L, Lago RC. Rapid preparation of fatty acid methyl esters from lipids. Lab Pract 1973; 22(6): 475-476, passim. [PMID: 4727126]

[24] Serra JL, Rodrigues AMDC, de Freitas RA, Meirelles AJA, Darnet $\mathrm{SH}$, Silva LHMD. Alternative sources of oils and fats from Amazonian plants: Fatty acids, methyl tocols, total carotenoids and chemical composition. Food Res Int 2019; 116: 12-9.

[http://dx.doi.org/10.1016/j.foodres.2018.12.028] [PMID: 30716906]

[25] Wagner H, Bladt S, Zgainski EM. Plant Drug Analysis. 1st ed. New York: Springer-Verlag Berlin Heidelberg 1984

[http://dx.doi.org/10.1007/978-3-662-02398-3]

[26] Wagner H, Bladt S. Plant Drug Analysis: A Thin Layer Chromatography Atlas. 2001.
[27] Khalid MN, Shameel M, Ahmad VU, Shahzad S, Leghari SM. Studies on the bioactivity and phycochemistry of microcystis aeruginosa (cyanophycota) from sindh. Pak J Bot 2010; 42(4): 2635-46.

[28] Stahl E. Thin-Layer Chromatography: A Laboratory Handbook 1969.

[29] Santos P, de Aguiar AC, Viganó J, Boeing JS, Visentainer JV, Martínez J. Supercritical $\mathrm{CO}_{2}$ Extraction of Cumbaru Oil (Dipteryx Alata Vogel) Assisted by Ultrasound: Global Yield, Kinetics and Fatty Acid Composition. J Supercrit Fluids 2016; 107: 75-83.

[http://dx.doi.org/10.1016/j.supflu.2015.08.018]

[30] Trentini CP, Cuco RP, Cardozo-Filho L, da Silva C. Extraction of macauba kernel oil using supercritical carbon dioxide and compressed propane. Can J Chem Eng 2019; 97(3): 785-92.

[http://dx.doi.org/10.1002/cjce.23236]

[31] Pinto RHH, Sena C, Santos OV, Da Costa WA, Rodrigues AMC, Carvalho RN. Extraction of bacaba (Oenocarpus Bacaba) oil with supercritical $\mathrm{CO}_{2}$ : Global yield isotherms, fatty acid composition, functional quality, oxidative stability, spectroscopic profile and antioxidant activity. Grasas Aceites 2018; 69(2)

[http://dx.doi.org/10.3989/gya.0883171]

[32] Suryawanshi B, Mohanty B. Modeling and optimization of process parameters for supercritical $\mathrm{CO}_{2}$ extraction of argemone mexicana (L.) seed oil. Chem Eng Commun 2019; 206(8): 1087-106. [http://dx.doi.org/10.1080/00986445.2018.1547712]

[33] Bouazzaoui N, Bouajila J, Camy S, Mulengi JK, Condoret JS. Fatty acid composition, cytotoxicity and anti-inflammatory evaluation of melon (Cucumis Melo L. Inodorus) seed oil extracted by supercritical carbon dioxide. Sep Sci Technol 2018; 53(16): 2622-7. [http://dx.doi.org/10.1080/01496395.2018.1464579]

[34] Subroto E, Widjojokusumo E, Veriansyah B, Tjandrawinata RR. Supercritical $\mathrm{CO}_{2}$ extraction of candlenut oil: process optimization using Taguchi orthogonal array and physicochemical properties of the oil. J Food Sci Technol 2017; 54(5): 1286-92. [http://dx.doi.org/10.1007/s13197-017-2542-7] [PMID: 28416879]

[35] Jesus SP, Calheiros MN, Hense H, Meireles MAA. A simplified model to describe the kinetic behavior of supercritical fluid extraction from a rice bran oil byproduct. Food Public Health 2013; 3(4): 215-22. [http://dx.doi.org/10.5923/j.fph.20130304.05]

[36] de Oliveira AIT, Mahmoud TS, do Nascimento GN, da Silva JFM, Pimenta RS, de Morais PB. Chemical composition and antimicrobial potential of palm leaf extracts from babaçu (Attalea speciosa), Buriti (Mauritia flexuosa), and Macaúba (Acrocomia aculeata). Scientific World Journal 2016; 20169734181 [http://dx.doi.org/10.1155/2016/9734181] [PMID: 27529077]

\section{(C) 2021 Chañi-Paucar et al.}

This is an open access article distributed under the terms of the Creative Commons Attribution 4.0 International Public License (CC-BY 4.0), a copy of which is available at: https://creativecommons.org/licenses/by/4.0/legalcode. This license permits unrestricted use, distribution, and reproduction in any medium, provided the original author and source are credited. 